\title{
認知的要因が特定悪臭物質の快不快に及ぼす影響： 臭気順応計測システムによる計測
}

\author{
戸田＼cjkstart英樹，斉藤 幸子，杉山 東子， \\ 後藤 なおみ，小早川 達
}

\begin{abstract}
特定悪臭物質の酢酸エチル, 硫化水素, アンモニアについて, 臭気への認知要因を教示で実験操作して, 臭気の快不快度への影響度合いを調べた。実験では，臭気の濃度と提示時間を制御して提示し，実験参加者 がスライドバーによって連続的に評定した強度応答をリアルタイムで収録する臭気順応計測システムを用 いた。 154 人の実験参加者は，提示される臭気について「健康によい」「健康に悪い」「どちらでむない」のう ち，ぞれかひとつの教示を受けた直後，いずれかの悪臭の感覚的強度を 10 分間リアルタイムで評定し，終了 後, 快不快度を評価した。 その結果，特定悪臭物質の快不快度においても，教示の影響が現れたが，影響の 程度は悪臭物質やその濃度によって異なった。酢酸エチルでは教示の効果が有意で，「健康によい」というポ ジティブ教示群は,「健康に悪い」というネガティブ教示群よりも快に感じた. 硫化水素では, 低濃度の場合 にのみ，教示の効果がみられ，ネガティブ教示群はポジティブ教示群よりも，また，コントロール教示群は ポジティブ教示群よりも不快に評定された。アンモニアについては教示要因の影響はみられなかった。これ らの結果は，公害臭気の対策で難題であった快不快の個人差の問題の解明に一歩踏み込むことができた。今 後, 臭気に対する順応過程の個人差やそれに関わる認知的要因を考慮することによってより実情に則した臭 気対策が期待される。
\end{abstract}

\section{1. 緒言}

臭気公害の対策が一筋縄でいかないことの大きな理由 の一つとして，臭気に対する快不快の個人差が挙げられ る. 個人差は主観的なあので公害対策にはなじまないと する考え屯あるが，一見バラバラにみえる評定值む，外 からは見えないが，そこに至る共通の心理的過程がある 場合が多い。それらを明らかにし悪臭現場の理解を深め ることは，より実情に則した悪臭対策を可能にすると思 われる，本研究では，個人差を引き起こす要因として， 臭気に対する認知的な内容の違いに注目した。つまり, 臭気に対して個人が持っている認知的内容の違いによっ て快不快の個人差が引き起こされることに注目した。筆 者らは既に，一定時間臭気を変動させて提示する変動臭 気提示装置 ${ }^{1,2)}$ を用いて, 变動臭気に対する順応過程に 個人差があり快不快にも影響すること ${ }^{3)}$, トリエチルア ミンの多様な順応/慣れの過程を 5 つの型に分けられる こと ${ }^{4)}$, 型によって快不快度や臭気の認知内容が異なる こと など，臭気の順応/慣れ過程の個人差と快不快, 認 知内容の関係を明らかにしてきた。これら一連の研究
は，実験参加者が臭気に対して持った認知的内容が異な り，それと快不快が対応して変化していたことを示す が，認知的内容は実験参加者が実験中に感じたもので， 操作的に統制されたものではない。このような認知的内 容を操作的に統制する方法として, 実験参加者への「教 示」の操作がある。「教示」は実験参加者に実験前に行う 説明の心理学的用語である。実験前に，異なる教示に よって, 実験参加者に, 臭気の認知的内容について異な る情報を与え, isobornyl acetate を20 分間同一濃度で 提示したところ,「健康によい」と教示を受けた群と「健 康に悪い」と教示を受けた群とでは, 後者の方がより不 快に感じることが報告された ${ }^{6)}$ 。 そこで筆者らは，日本 人にとって馴染みのないにおいであるアネトールを用い て, 実験参加者に同様の異なる教示を与え, アネトール 臭気を 20 分間提示した. その結果, 「健康によい」と教 示を受けた群と「健康に悪い」と教示を受けた群とでは, 後者の方がより不快に感じること7)などを明らかにして きた。本研究では，このような快不快の変化が特定悪臭 物質として指定されている酢酸エチル，硫化水素，アン モニアで生じるかについて検討した。

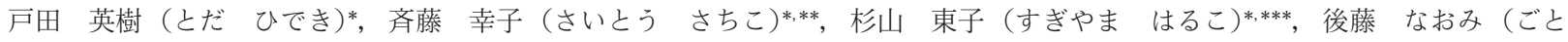
うなおみ)*, 小早川 達(こばやかわ たつ)*

*独立行政法人 産業技術総合研究所 人間福祉医工学研究部門 $\mathbf{T} 305-8566$ 茨城県つくば市東 1-1-1つくば中央第 6

**斉藤幸子味覚嗅覚研究所 テ305-0042 茨城県つくば市下広岡 410-151

***筑波大学 人間総合科学研究科 心理学専攻 $\overline{\mathbf{T}} 305-8572$ 茨城県つくば市天王台 1-1-1 


\section{2. 方法}

\section{1 臭気順応計測システム}

本実験は变動臭気提示装置を改良した臭気順応計測シ ステム (図ー1) を使用して行った. 本システムは提示臭 気の条件設定 (時間, 濃度), 実験参加者への臭気の提 示，実験参加者が行う実時間強度データの記録を行う。

\section{2 提示臭気}

臭気物質は䣷酸エチル，硫化水素，アンモニアの 3 種 類とした。酢酸エチル，硫化水素の濃度は臭気強度評定 で弱い，中等度の 2 段階としたが，アンモニアは安全性 を考え濃度 1 段階とした。提示流量は毎分 $1 \mathrm{~L}$ とした が，アンモニアは $15 \mathrm{ppm}$ では強度が弱かったため毎分 $4 \mathrm{~L}$ とした。

各濃度は，酶酸エチルの場合は， $2 \mathrm{~mL} / 1 \mathrm{~L}, 6 \mathrm{~mL} / 1 \mathrm{~L}$ （100\%の酢酸エチルバブリングガス/䣷酸エチル十無臭 空気）で，硫化水素の場合は $100 \mathrm{~mL} / 1 \mathrm{~L}, 300 \mathrm{~mL} / 1 \mathrm{~L}$ (4 $\mathrm{ppm}$ のボンベからの硫化水素 $/ \mathrm{H}_{2} \mathrm{~S}+$ 無臭空気), アンモ ニアの場合は，ボンベ $(15 \mathrm{ppm})$ から希䆏なしで，流量 が $4 \mathrm{~L} / \mathrm{min}$ であった。

\section{3 実験参加者}

実験参加者は, 初めに, 実験内容を説明され, 途中で やめることができることなども話されて，実験参加に同 意するから゙うか確認された。実験参加者は簡単な性格に 関する質問によって，外向性，内向性，不安傾向，温和 などが調べられ，群間で性格に偏りがでないように，ポ ジティブ教示群，ネガティブ教示群，統制教示群のどれ かに振り分けられた。次にスティック型嗅覚同定能力検 査 (Odor Stick Identification Test: OSIT) ${ }^{8), 9)}$ によっ て, 嗅覚同定能力が測定され, 嗅覚が正常であるかどう か調べられ, 正常とされた者のみ実験に参加した。提示 臭気，教示内容の違いによる実験参加者人数の内訳を表 -1 に示す. 実験参加者 154 人の内 12 人は同一人物で, 異なる 2 つの実験に参加したが，2つの実験は 4 か月〜

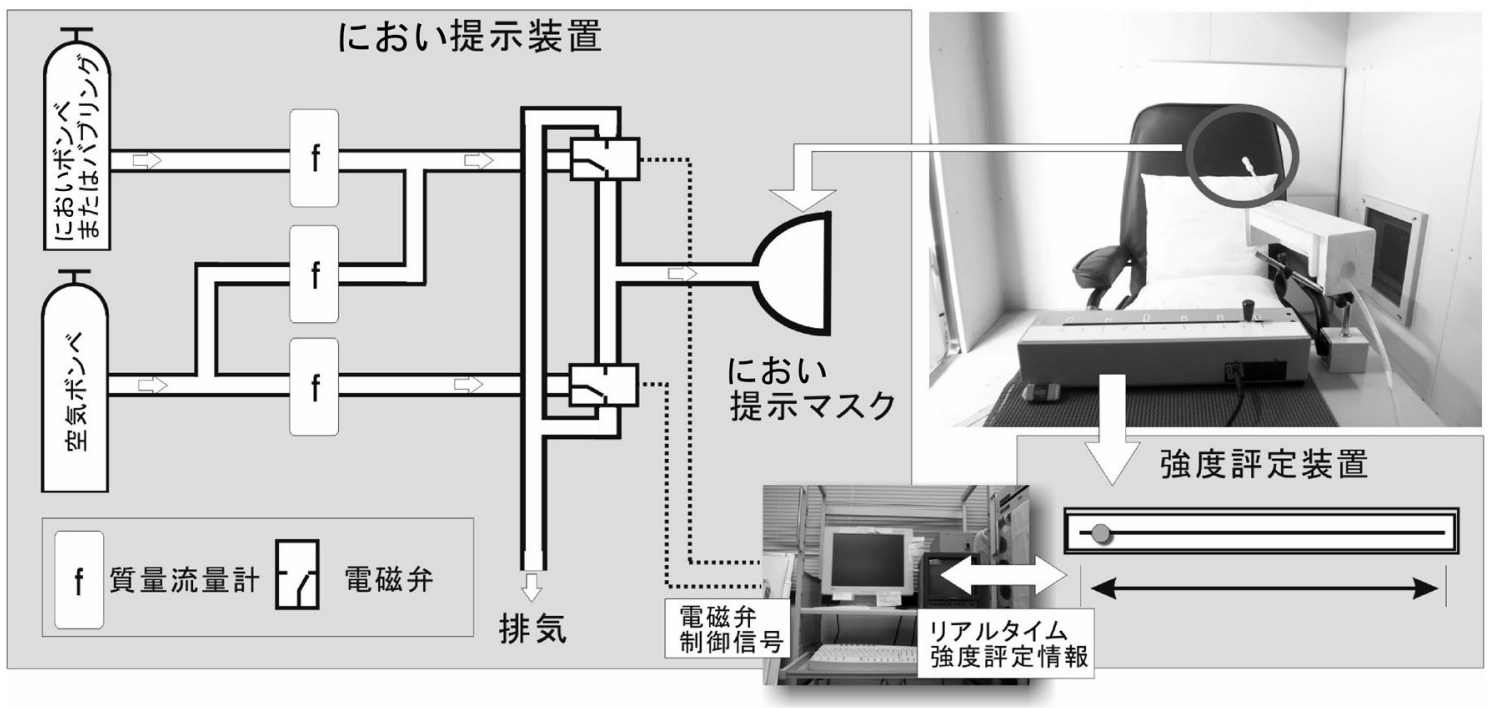

図-1 臭気順応計測システム

中央下写真にあるコンピューターが図左のに拈い提示装置を制御して, 右上の写真丸部につけられたにおい提示マスクに臭気または 無臭空気を切り替えて提示する。実験参加者は強度評定装置のレバーを連続的に左右に動かして，臭気強度をリアル夕イムで評定する。 この情報はコンピューターに伝えられ，実験者の観察するモニターに表示されると共にデー夕収録される。においの発生は, におい提 示装置の左上に示されたボンべ（においが常温で気体の場合）またはバブリング（においが常温で液体の場合）によって行い，空気で 希釈して任意の濃度にし, 電磁弁の作動で空気の切り替えと時間の制御を行う.

表 -1 実験参加者人数の内訳

\begin{tabular}{c|c|c|c|c}
\hline & ポジティブ教示群 & コントロール教示群 & ネガティブ教示群 & 計 \\
\hline 酢酸エチル & 19 人 & 11 & 16 & 46 \\
\hline 硫化 水 素 & 19 & 22 & 23 & 64 \\
\hline アンモニア & 15 & 14 & 15 & 44 \\
\hline 計 & 53 & 47 & 54 & 154 \\
\hline
\end{tabular}


14 か月（平均 7.9 か月）離れているので，影響はほとん どないと考え解析に加えた。

\section{4 実験手続き}

実験参加者は，臭気が提示される小部屋（図一2）に案 内され, 臭気が提示されるテフロンチューブの先に実験 参加者専用の嗅ぎロ（におい提示マスク）をつけ，嗅ぎ 方, 強度評定装置のレバーを左右に動かして強度を評定 する方法，実験中の姿勢などについて説明を受けた。説 明の最後に,「これから提示される臭気はこのようなもの です」といって，臭気に対するポジティブ教示，ネガティ ブ教示，コントロール教示のどれかの教示を書いた紙を 渡され読むよう指示された。各教示の主な内容を表－2 に示す。その後, 実験参加者に専用の耳栓をつけ，テスト 臭気（濃度が 2 段階ある場合は薄い方）を約 10 秒間提示 して，においを感知できるかを確認した，その後，実験参 加者は臭気順応計測システムのにおい提示装置から提示 される臭気に対して, 強度評定装置 (スライドバー)を使 用して，感覚的強度をリアルタイムで評定した（図一2）. 臭気は 10 分間, 臭気の前に 10 秒間, 後に 2 分間, 臭気之 同じ流量の無臭空気を提示した。スライドバーで提示さ れた評定值はリアルタイムでコンピューターに伝えられ
記録された。実験参加者は，臭気あるいは無臭空気が提 示されている時間軸上に，それと対応したリアルタイム の強度評定值をモニターで確認した（図一2)。また，実験 中は別のモニターでにおいを嗅ぐ実験参加者の様子も確 認した. 臭気提示終了後, 実験参加者は, 提示された臭気 の快不快度を-100 (非常に不快) +100（非常に快）の ビジュアルアナログ尺度（VAS : Visual Analog Scale） で評定した。快不快の他にもにおい質や身体的な不快感 などを評定したが，本報告では割愛した。

全体の実験手順を以下に示す。アンモニアの場合は

(7) はない.

（1） 同意書の確認

（2）性格に関する質問（実験参加者の振り分けのため）

（3）嗅覚検査（スティック型嗅覚同定能力検査）

（4）提示臭気 1 のリアルタイム強度評定

（5） 快不快度の評定（-100～+100 VAS）

（6）休憩（15～20 分：性格検査完全版）

（7）提示臭気 2 （実験 1 とは別の濃度）のリアルタイ 么強度評定

(8) デブリーフィング

実験は酢酸エチル, 硫化水素, アンモニアの順に行い, それぞれ 15 か月，5 か月，6か月を要した。
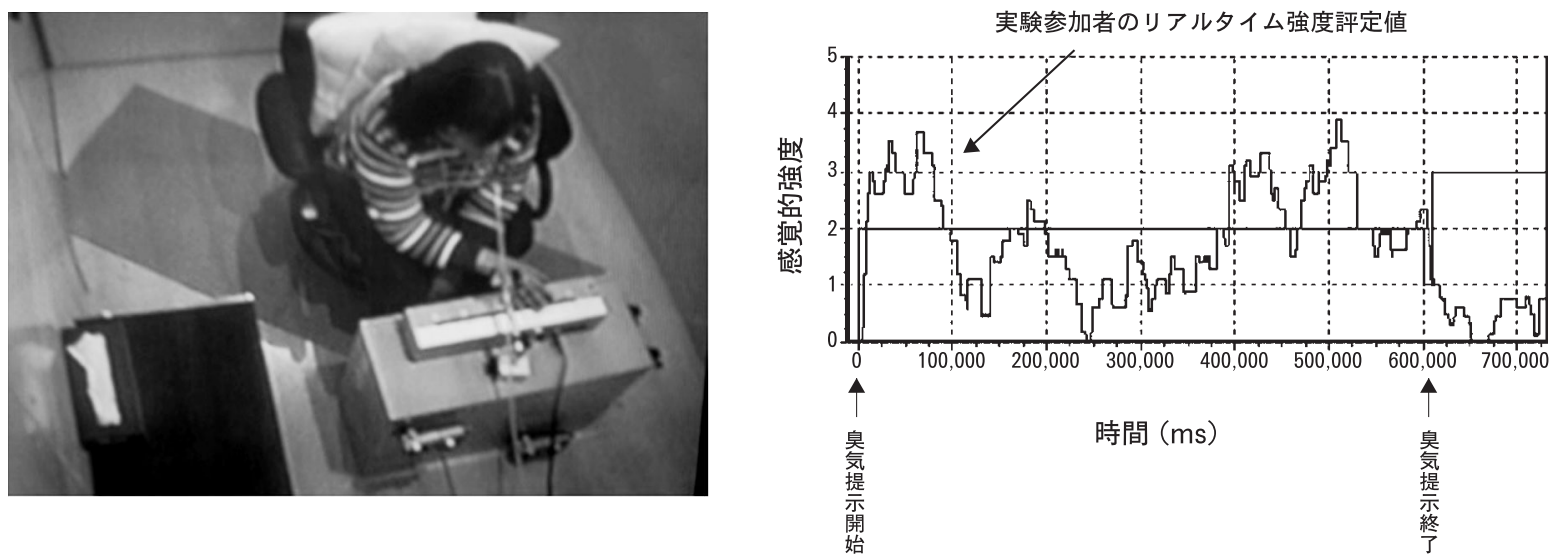

図－2 リアルタイム強度評定を行う実験参加者（左）とコンピューターに送られ，モニター上にリアルタイムで描かれ た提示臭気と強度評定値の情報

表－2ポジティブ教示群，ネガティブ教示群の各教示の主な内容

\begin{tabular}{|c|c|c|}
\hline & ポジティブ教示 & ネガティブ教示 \\
\hline 酷酸エチル & $\begin{array}{l}\text { リンゴなどフルーツフレーバー } \\
\text { の成分. アロマテラピー的な効 } \\
\text { 果. }\end{array}$ & 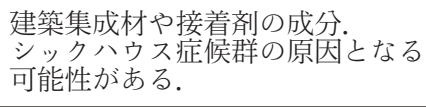 \\
\hline 硫化 水素 & $\begin{array}{l}\text { 新陳代謝を高め温感効果をむた } \\
\text { 马美白効果. } \\
\text { アロマテラピー的な㑯面. }\end{array}$ & $\begin{array}{l}\text { 農薬の精製に用いられる薬品. } \\
\text { 量度の場合には, めまい, 吐き } \\
\text { 気. 今回の実験極めて低い濃度. }\end{array}$ \\
\hline アンモニア & $\begin{array}{l}\text { 食品製造, 清涼感. } \\
\text { 美容健康によ。 }\end{array}$ & 肥料, 水生生物に悪影響. \\
\hline
\end{tabular}




\section{3. 結果}

先ず，提示された 5 つの臭気がどの程度の強さであっ たかを調べるため, コントロール群について, 各実験参 加者が連続的に評定したリアルタイム感覚強度評定值 （50 ms 毎に記録）の総和から平均強度を算出した（表一 3). 同一臭気では, 高濃度は低濃度よりも強く評定され た（酢酸エチル : $t(10)=3.08, p<.05$; 硫化水素 : $t(21)$ $=2.48, p<.05)$. また, アンモニアは 5 臭気の中で一番 弱く評定された。しかし, 酢酸エチル, 硫化水素の低濃 度の臭気と比較（1 要因分散分析）すると, 3 臭の強度間 に差があるとはいえなかった。

次に，各臭気について別々に，教示の違いが臭気の快 不快度に及ぼす影響を調べるため分散分析を行った。酢 酸エチル, 硫化水素については, 教示要因, 濃度要因の 2 要因分散分析を, アンモニアでは教示要因の 1 要因分 散分析を行った。結果を図ー3に示す。酢酸エチルの場 合は, 教示要因 $(F(2,43)=7.86(p<.01))$, 濃度要因 $(F(1,43)=14.25(p<.01))$ のどちらむ有意であった。 すなわち, 教示の違いによっても, 濃度の違いによって 屯，快不快度に差がみられた。交互作用は有意でなかっ た。多重比較 (Tukeyの HSD 法) を行うと, ネガティ ブ教示群とポジティブ教示群の間に差がみられ（ $p<$ .01)), コントロール教示群とポジティブ教示群の間には 差の傾向がみられた. 硫化水素の場合は, 教示要因, 濃 度要因のよ゙ちらも有意でなかったが，交互作用は有意で あった $(F(2,61)=4.54(p<.05))$. そこで, 単純主効 果の検定を教示要因について行うと, 低濃度についての み，教示の効果が有意であった $(F(2,61)=3.55(p<$ .05)). 多重比較ではポジティブ教示群とネガティブ教示 群 $(p<.05)$, ポジティブ教示群とコントロール教示群 ( $p$ <.05）との間で差がみられた。アンモニアについては教 示要因の効果はみられなかった。

\section{4. 考察}

今回の結果から, 先入観といった臭気の認知的要因 が，特定悪臭物質の快不快度にも影響することを示し た。 また，影響の仕方はにおいや濃度によって異なり一 様でないことを示した。酢酸エチルは，教示の効果を受

\section{表－3 コントロール群のリアルタイム強度評定值の} 平均と標準誤差 (SE)

\begin{tabular}{l|c|c}
\hline & $\begin{array}{c}\text { 低濃度 } \\
\text { 平均強度 }(\mathrm{SE})\end{array}$ & $\begin{array}{c}\text { 高濃度 } \\
\text { 平均強度 }(\mathrm{SE})\end{array}$ \\
\hline 酢酸エチル & $1.43(0.28)$ & $2.39(0.30)$ \\
硫化水素 & $1.08(0.18)$ & $1.33(0.14)$ \\
アンモニア & $0.91(0.16)$ & \\
\hline
\end{tabular}

けやすかったが，この臭気の持つにおい質の多様性が影 響していると考えられる。硫化水素になると低濃度での み教示の影響がみられたが，低濃度の方がにおいの質を 特定しにくかったためと考えられる。このことは, 坂井 $ら^{7)}$ が日本人に馴染みのないアネトールについて同様な 実験を行っており，そこで快不快について顕著な効果が みられたことからあうなずける。アンモニアでは教示の 効果がみられなかった。これは安全性を考えて低濃度の あのを用意したことにも原因があるかもしれない.リア ルタイムで計測した平均強度評定值の平均強度む一番低 く，不快度も余り大きくなかった。しかし，リアル夕イ 么平均強度評定值は他の 2 つの低濃度臭気と有意な差は みられなかった。 今後, 平均強度評定值の個人差やにお いの質についての解析も含め検討したい。このように特 定悪臭物質であっても, トップダウン的に与えられた教 示，すなわち認知的要因によってその評価が異なってく ることが示されたが, その程度は臭気の種類や濃度（強 度）によってさまざまであるといえる。このことは臭気 公害現場において, 臭気に対する評価が風評やマスコミ の影響を受けやすいことを示しており，臭気の苦情への 対応もこのような臭気の側面を充分理解して，対処する ことが必要である。具体的には，間違った風評に住民が

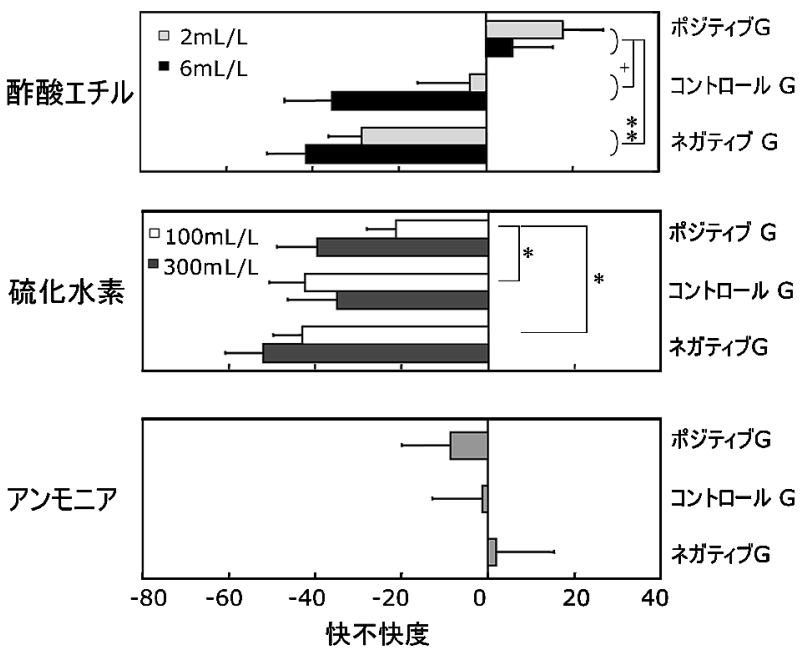

図－3 異なる教示を与えられた実験参加者群の平均快不快度

ポジティブ G はポジティブ教示群を，コントロール G はコ ントロール教示群を, ネガティブ G はネガティブ教示群を さす. 酢酸エチルの場合は, 教示要因 $(F(2,43)=7.86(p$ $<.01))$, 濃度要因 $(F(1,43)=14.25(p<.01))$ 共快不快 度に差がみられた。交互作用は有意でなかった。多重比較 (Tukeyの HSD 法) では, ネガティブ Gとポジティブ G の間に差がみられた $(p<.01))$. 硫化水素の場合は, 教示要 因, 濃度要因のどちらあ有意でなく, 交互作用が有意であっ た $(F \quad(2,61)=4.54 \quad(p<.05))$. 単純主効果の検定では, 低濃度の場合に, 教示の効果がみられた $(F(2,61)=3.55$ $(p<.05))$. 多重比較を行うと, ポジティブ $\mathrm{G}$ とネガティブ $\mathrm{G}(p<.05)$ の間, ポジティブ $\mathrm{G}$ とコントロール $\mathrm{G}(\mathrm{p}<$ .05）の間で差がみられた。 アンモニアについては教示要因 による差はみられなかった。

$* *: \mathrm{p}<.01, *: \mathrm{p}<.05,+: .05<\mathrm{p}<.10$ 
惑わされないように工場側がその臭気の安全性について 十分な情報公開を行うことが必要である。特に, 性格の はっきりしない曖昧なにおいは影響を受けやすい. 臭気 公害で発生しているさまざまな化学物質について，その 臭気質を調べた研究では, 多くの臭気が多様な記述語で 表現され，人によっても異なっていたこと ${ }^{10)}$ が報告され ており，臭気公害で発生されるにおいにははっきりしな い曖昧なむのが多く含まれることを示唆する。また，今 回の結果では, ポジティブな教示によって評価が変わる が，ネガティブな教示ではコントロール教示群の評価と あまりかわらないことが示された。このことは実験参加 者が実験前に蓄積していた情報が「健康に悪い」といっ たネガティブなものだったと考えられ，正しい情報公開 によってこれまでの評価を変えられる可能性を示してい る. 何か分からないにおいについては不快方向に評価さ れる傾向があり, これが工場などの発生源の悪いイメー ジと結びつくと評価はますます悪くなるだろう。また， 場合によっては, このような情報公開と併わせて, 現場臭 気を採集して, 被害者や第三者による認知的要因の影響 度を測定して示すことも有効であろう. 現在, 筆者らは現 場臭気を採集して計測可能な臭気順応計測システムも開 発している.

今後の研究的課題としては, 今回まだ解析していない 順応/慣れ過程の型や臭気質についての解析, 教示 (先入 観) の影響の受けやすさと当該臭気の特徵 (順応/慣れ過 程の型, 臭気質, 臭気強度, 快不快度) の関係加ら, 影 響の度合いを予測できないかの検討, 坂井ら ${ }^{11)}$ が一部発 表しているが, 認知的要因の影響に関わる脳機能のさら なる解明である. 今回の結果は, 臭気対策で難題であった 快不快の個人差の問題の解明に一歩踏み込む内容を示す ことができた. 今後, 臭気に対する認知的要因を考慮する ことによってより実情に則した臭気対策を期待したい.

\section{5. 結語}

特定悪臭物質の䣷酸エチル, 硫化水素, アンモニアに ついて, 臭気への認知要因を教示で実験操作して, 臭気 の快不快度への影響度合いを，臭気順応計測システムを 用いて調べた。 その結果, 特定悪臭物質の快不快度にも 教示の影響が現れた. 影響の程度は悪臭物質やその濃度 によっても異なった. 䣷酸エチルでは教示の効果が有意 で,「健康によい」というポジティブ教示群は,「健康に 悪い」というネガティブ教示群よりも快に感じた. 硫化 水素では, 低濃度の場合にのみ, 教示の効果がみられ, ネガティブ教示群はポジティブ教示群よりも, また, コ ントロール教示群はポジティブ教示群よりも不快に評定 された. アンモニアについては教示要因の影響はみられ なかった。これらの結果は, 臭気公害の対策で難題で
あった快不快の個人差の問題の解明に一歩踏み込むこと ができた。 今後, 臭気に対する順応過程の個人差やそれ に関わる認知的要因を考慮することによってより実情に 則した臭気対策が期待される.

\section{謝辞}

本研究は環境省公害防止等試験研究費 (公害・地域密 着型）地球環境保全試験研究費によって実施された。

キーワード : 悪臭, 認知的要因, 快不快度, 臭気順応計 測システム，におい

\section{参考文献}

1 ) 斉藤幸子, 飯尾 心, 吉田倫幸, 佐渡山巠兵, 綾部早穂, 早野陽子: 变動臭気呈示装置による不快度計測一持続的呈 示之断続的呈示の比較一, 第 26 回味と匂のシンポジゥム 発表論文集，321-324，（1992）。

2) 関根道昭, 斉藤幸子, 飯尾 心 : 連続的に提示させた臭 気に対する金属酸化物半導体ガスセンサーの応答特性，臭 気の研究，26，46-51，(1995).

3 ) Saito, S., Iio, K., Yoshida, T., Ayabe-Kanamura, S. and Sadoyama, T. (eds. Kurihara, K., Suzuki, N. and Ogawa, H.) : (1994), Effects of fluctuating odor on odor intensity and annoyance, in Olfaction and Taste XI, 345-346, Springer-Verlag.

4 ) 斉藤幸子, 飯尾 心, 小早川達, 後藤な扔み: 持続提示す る臭気に対する感覚的強度の多様な時間依存性，におい。 か打り環境学会誌, 35, 17-21, (2004).

5 ) Saito, S., Kobayakawa, T., Gotow, N. and Iio, K. : Variety of time intensity curves during offensive odor exposure and its relation with perceptual and cognitive aspects, XVI ECRO Congress Program \& Abstracts, 107, (2004).

6 ) Dalton, P. : Odor perception and beliefs about risk, Chem. Senses, 21, 447-458, (1996).

7 ) 坂井信之, 小早川達, 斉藤幸子: 認知的要因がにおいの 知覚と順応過程に及ぼす影響, におい・打り環境学会 誌, 35, 22-25, (2004).

8 ) 斉藤幸子, 綾部早穂, 内藤直美, 後藤なおぬ, 小早川達, 三瀬美也子, 高島靖弘 : 日本人のための嗅覚同定能力測定法 の開発 一スティック型・カード型におい提示試料の妥当 性の検討一, に扎い.か抢り環境学会誌，34，1-6, (2003).

9 ) Saito, S., Ayabe-Kanamura, S., Takashima, Y., Gotow, N., Naito, N., Nozawa, T., Mise, M., Deguchi, Y. and Kobayakawa, T. : Development of a smell identification test using a novel stick-type odor presentation kit, Chem. Senses, 31, 379-391, (2006).

10）斉藤幸子, 飯田健夫, 坂口 豁, 児玉廣之 : 悪臭の質の記 述の特徽, 臭気の研究, 28, 32-43, (1997).

11）坂井信之, 小早川達, 戸田英樹, 山内康司, 斉藤幸子 : 二 オイに対する教示が嗅覚脳内情報処理に及ぼす影響, にお い・かおり環境学会誌，37，9-14，(2006). 


\title{
The effects of cognition on the hedonics of off ensive odorants by a measurement system for odor adaptation
}

\author{
Hideki TODA*, Sachiko SAITO*,**, Haruko SUGIYAMA*,**, \\ Naomi GOTOW*, Tatsu KOBAYAKAWA* \\ * Institute for Human Science and Biomedical Institute of Advanced Industrial Science \\ and Technology, Tsukuba Cetral 6, 1-1-1, Higashi, Tsukuba, Ibaraki, \\ 305-8566, Japan \\ ** Saito Sachiko Taste and Smell Institute, 410-151, Shimohirooka, Tsukuba, Ibaraki, \\ 305-0042, Japan \\ *** Doctoral program in Psychology Comprehensive Human Science, \\ University of Tsukuba, 1-1-1, Tennodai, Tsukuba, Ibaraki, \\ 305-8572, Japan
}

\begin{abstract}
We examined the effects of cognition on the hedonics of three typical offensive odor pollutants. One hundred fifty-four healthy women and men were exposed to one of three odors (ethyl acetate, hydrogen sulfide, or ammonia), which are regulated as odor pollutants in Japan, after being told that the odorant was healthful, neutral, or harmful. Participants continuously rated the odor intensity for 10 min using a slide lever. A measurement system for odor adaptation controlled the concentration and duration of the presented odor, and recorded the intensity of the responses every $50 \mathrm{~ms}$. After the presentation of the odorant, the participants ranked the hedonics (pleasantnessunpleasantness) of the odor using a visual analog scale from -100 (very unpleasant) to +100 (very pleasant).

The results revealed the effects of cognition on the hedonics of offensive odorants. These effects, however, were different for the three odor pollutants ; the largest effects were observed with ethyl acetate, whereas the smallest effects were observed with ammonia. These results should help to address problems associated with individual differences in the regulation of odor pollution.
\end{abstract}

Key words : offensive odors, cognitive effects, hedonics (pleasant-unpleasantness), measurement system for odor adaptation, odor 